\title{
EVOLUÇĀO TECNOLÓGICA EM SISTEMA DE INFORMAÇÃO
}

\section{Antonio Anastácio da Cruz}

Decorrente das mudanças da sociedade industrial para a sociedade da informação e do conhecimento, tanto no cenário mundial quanto no Brasil, vive-se uma palavra de ordem que impulsiona, agride e até sufoca que é a palavra mudança. Vários autores têm escrito artigos, livros sobre essas mudanças, buscando compreensão sobre essa nova era.

Há séculos, essa organização social criada pelo homem, acumula a produção do conhecimento provocando um certo saturamento em alguns de seus serviços/produtos, provocando com isso um certo acúmulo de informação, às vezes não disponível em bibliotecas, o que traz certa insatisfação e frustração no usuário porque não consegue ver suas necessidades de informação atendidas.

Hoje o estabelecimento de novas parcerias, nos permite filtrar, organizar e reunir informações que sejam úteis aos usuários, independentemente do lugar de localização, os órgãos mentores da informação precisam sair da situação de posse e investir na filosofia de acesso. Precisamos assumir a posição de provedor de acesso da informação e para isso é preciso adaptar-nos a realidade do momento, isto porque os usuários de hoje são diferentes daqueles da era industrial.

Para impulsionar o desenvolvimento da sociedade, a informação é um fator imprescindível, porém, há o fator político que os países podem ser classificados de acordo com a qualidade e quantidade de informação que tem em seu poder. Transferência de informação pode gerar diversos problemas, como a demanda de produtos supérfluos que os transforma em armas poderosas, como elemento no bloqueio ou boicote a determinados países.

Todos os países se preocupam com a economia política de informação, tanto os avançados quanto aqueles em desenvolvimento. Nos países avançados o setor que mais emprega mão de obra é a 
industria da informação. É importante que a política de informação seja formada de modo a permitir a concepção moderna de sistema como a preocupação de preservar a memória nacional, com o uso de nova tecnologia, assegurando a recuperação capaz de tornar a informação acessível a todos.

Os planejamentos bibliotecários associados à racionalidade administrativa devem ser complementados com a comunicação interna e externa nas organizações.

Nos países de terceiro mundo os bibliotecários necessitam desenvolver um senso crítico em relação à política da informação, não podem ficar omissos, nem alienados, observando informações de modo passivo, precisam desenvolver suas idéias e percepções questionando o assunto, uma vez que é parte ativa desse processo. É preciso que lutem para efetivar sua participação colaborando na elaboração e disseminação de critérios que condizem quais as necessidades que permite assegurar o compartilhamento da informação e crie sistemas eficazes e participantes para sua difusão.
Sobre os avanços tecnológicos a contribuição política do bibliotecário fundamenta-se de que o aparecimento e a fixação de uma nova tecnologia tem que ter o respaldo da sociedade de acordo com o seu nível de conhecimento. Nesse momento surgem oportunidades para os bibliotecários ampliar sua visão profissional e acompanhar a evolução do mercado da informação, para estar sempre informado e assim evitar perder espaço para profissionais de outras áreas. O bibliotecário deve estar ciente de que o uso das novas tecnologias da informação constituem em fatos importantes para a informatização da sociedade, pois potencializa a capacidade de produzir novos conhecimentos.

Com a massificação da cultura e o excesso de informação, é preciso desenvolver um meio de passarmos aos usuários toda essas informação de maneira que os mesmos não tenham dificuldade para localiza-la ou obtê-la.

Os catálogos, índices e esquemas de classificação foram planejados para auxiliar os usuários nas busca de informações, porém, os bibliotecários os transformavam em instrumentos de uso 
próprio, não dando relevância aos usuários. Dentro desse e outros problemas que os bibliotecários erroneamente tinham, nos dias de hoje se tornaram ativos e orientados aos usuários com prestação de serviços de alto nível com grande uso dos meios tecnológicos da informação.

As atuações dos bibliotecários passaram a ser mais dinâmicas, voltadas para os usuários, não sendo mais aquela biblioteca estática voltada ao próprio sistema. Hoje em dia vê-se que profissionais da informação estão orientados a melhor auxiliar os usuários, dando-lhes mais segurança no seu trabalho de acesso à informação.

Procurando melhor atender os usuários, tem-se procurado uma reestruturação dos catálogos onde reúne todas as informações das matérias existentes, independentemente da sua localização na biblioteca. São essas e outras mais inovações que se deve ter para melhorar uma biblioteca. Devemos enfatizar que a biblioteca e os bibliotecários precisam manter-se um passo adiante das tendências sociais e das expectativas dos seus usuários, pois assim poderão criar serviços e produtos que satisfaçam os que mais necessitam da informação, os usuários.

\section{REFERÊNCIAS}

AMARAL, S. A. do. Serviços bibliotecários e desenvolvimento social: um desafio profissional. Rev. Ciência da Informação, Brasília, v.24, n.2, 1995.

FIGUEIREDO, Nice. Técnicas e idéias para promover o uso da informação. Rev. Brasileira de Biblioteconomia e Documentação. São Paulo, v.21, n.3/4, p.85-100, jul./dez. 1988.

CARVALHO, I. C. L.; KANISKI, A. L. A sociedade do conhecimento e o acesso a informação: para que e para quem? Rev. Ciência da Informação, Brasília, v.29, n.3, p.33-39, set./dez.2000.

ANTONIO ANASTÁCIO DA CRUZ

Aluno do $3^{\circ}$ ano do Curso de Ciência da Informação com

Habilitação em Biblioteconomia da Pontifícia Universidade Católica de Campinas

Aceito para publicação em: 30/11/200 